\title{
Pengaruh Perbedaan Kadar Oksitosin Melalui Pemijatan Oksitosin Terhadap Jumlah Perdarahan pada lbu 2 Jam Postpartum
}

Desi Sarli ${ }^{1}$ Masrul ${ }^{2}$, Meilinda Agus $^{3}$

\begin{abstract}
Abstrak
Upaya penanganan perdarahan postpartum adalah dengan pemberian oksitosin yang mempunyai peranan penting dalam merangsang kontraksi otot polos uterus sehingga perdarahan dapat teratasi.Hormon oksitosin dapat dihasilkan melalui rangsangan pemijatan oksitosin yang akan mempercepat kerja saraf parasimpatis untuk menyampaikan perintah ke hipotalamus untuk menghasilkan oksitosin. Tujuan penelitian ini adalah untuk mengetahui pengaruh perbedaan kadar oksitosin melalui pemijatan oksitosin terhadap jumlah perdarahan pada ibu 2 jam postpartum. Penelitian menggunakan desain eksperimen. Penelitian ini dilaksanakan \pm 6 bulan dengan jumlah sampel 64 orang. Pengolahan data dilakukan dengan komputerisasi. Data disajikan dalam bentuk distribusi frekuensi dan selanjutnya dilakukan uji independen $t$-test, uji korelasi dan regresi untuk mengetahui pengaruh hubungan kedua variabel. Hasil penelitian perbedaan kadar oksitosin pada ibu 2 jam postpartum pada kelompok intervensi mempunyai rata-rata kadar oksitosin $47.16 \mathrm{pg} / \mathrm{ml}$ dengan standar deviasi $17.583 \mathrm{pg} / \mathrm{ml}$,sedangkan kadar oksitosin pada kelompok kontrol $29.86 \mathrm{pg} / \mathrm{ml}$ dengan standar deviasi $17.532 \mathrm{pg} / \mathrm{ml}$ dengan nilai $\mathrm{p}<0,05$. Rata-rata jumlah perdarahan pada kelompok intervensi $175.00 \mathrm{ml}$ dengan standar deviasi $48.894 \mathrm{ml}$,sedangkan jumlah perdarahan pada kelompok kontrol $247.06 \mathrm{ml}$ dengan standar deviasi $72.093 \mathrm{ml}$ dengan nilai $\mathrm{p}<0,05$. Hasil uji korelasi didapatkan hubungan kadar oksitosin terhadap jumlah perdarahan menunjukkan hubungan sedang ( $r=0,482)$. Hasil uji statistik didapatkan ada perbedaan kadar oksitosin terhadap jumlah perdarahan $(p<0,05)$. Terdapat perbedaan yang bermakna antara kadar oksitosin ibu 2 jam postpartum pada kelompok intervensi dan kelompok kontrol.Terdapat perbedaan yang bermakna antara jumlah perdarahan ibu 2 jam postpartum pada kelompok intervensi dan kelompok kontrol. Semakin tinggi kadar oksitosin maka jumlah perdarahan semakin sedikit.
\end{abstract}

Kata kunci: Pemijatan oksitosin, oksitosin, jumlah perdarahan 2 jam postpartum

\section{Abstract}

Efforts to handling postpartum hemorrhage is to give oxytocin, which it is an important role in oxytocin stimulates uterine smooth muscle contraction, so that bleeding can be resolved. The hormone oxytocin can be generated through the stimulation of oxytocin massage that will accelerate parasympathetic nerves to deliver commands to the hipotalamus to produce oxytocin. The objective of this study was to determine effect of different levels of oxytocin trough massage of oxytocin on the amount of bleeding at 2 hours postpartum. This research use experimental design that was conducted \pm 6 months to 64 people. Data processing was done by computerized. The data presented in the form of a frequency distribution and performed an independen $t$-test and correlation test and regression to determine the effect ofthe relationship between the two variables. There is differences the levels of oxytocin at 2 hours postpartum in the intervention group had higher median levels of oxytocin $47.16 \mathrm{pg} / \mathrm{ml}$ with a standard deviation of $17.583 \mathrm{pg} / \mathrm{ml}$, whereas the levels ofoxytocin at 2 hours post partum control group $29.86 \mathrm{pg} / \mathrm{ml}$ with a standard deviation of $17.532 \mathrm{pg} / \mathrm{ml}$ with $p<0.05$. The average of bleeding in the intervention group was $175.00 \mathrm{ml}$ with a standard deviation of $48.894 \mathrm{ml}$, while the amount of bleeding at 2 hours postpartum control group $247.06 \mathrm{ml}$ with a standard 
deviation of $72.093 \mathrm{ml}$ with $p<0.05$. The results obtained correlation levels of oxytocin relation to 2 hours postpartum hemorrhage showed moderate relationship ( $r$ =0.482). The results of statistical tests found differences in the levels of oxytocin on the amount of bleeding at 2 hours postpartum $(p<0.05)$. There is differences between the levels of oxytocin 2 hours pos partum in the intervention group and the group control. There are significant difference between the hemorrhage 2 hours post partum in the intervention group and the group of high levels of oxytocin control.

Keywords: massage of oxytocin, oxytocin, amount of bleeding at 2 hours postpartum

Affiliasi penulis : 1. Program Studi Magister S2 Kebidanan FK UNAND (Fakultas Kedokteran Universitas Andalas Padang), 2. Laboratorium Biomedik Universitas Andalas 3. Bidan Praktek Mandiri Kota Padang dan Pariaman

Korespondensi : Desi Sarli, E-mail: desi_sarli@yahoo.com, Telp: 081267033306

\section{PENDAHULUAN}

Angka Kematian Ibu (AKI) akibat persalinan sampai saat ini masih merupakan salah satu masalah kesehatan dunia. Di Indonesia, AKI tahun 2012 adalah 359 per 100.000 kelahiran hidup, dibanding negaranegara di Asia Tenggara, angka ini adalah yang tertinggi. Hal ini sudah dapat dipastikan Indonesia tidak akan dapat mencapai target sesuai dengan target Millennium Development Goals (MDGs) berupaya menurunkan angka ini menjadi 102 per 100.000 kelahiran hidup pada tahun $2015 .^{1}$

Perdarahan merupakan penyebab kematian ibu bersalin yang memberikan kontribusi paling besar terhadap seluruh penyebab kematian ibu melahirkan. Penyebab kematian ibu bersalin yang lain diantaranya infeksi dan preeklamsia/eklamsia. Perdarahan pasca persalinan dan atonia uteri merupakan penyebab paling sering. Penyebab yang lain adalah retensio plasenta, robekan jalan lahir dan inversio uteri. $^{2}$

Perdarahan pasca persalinan merupakan kejadian yang tidak dapat diprediksi. Bila ini terjadi, maka merupakan suatu tragedi, sehingga sangat penting memperbaiki kualitas penanganan sehingga banyak nyawa ibu yang dapat diselamatkan. Di masa lampau sebagian besar penolong persalinan baru melakukan intervensi bila sudah terjadi perdarahan atau terjadi proses yang berjalan secara tidak normal. ${ }^{2}$

Rumah Sakit Umum Pusat (RSUP) Dr. M. Djamil merupakan rumah sakit rujukan di Sumatara Barat. Hasil dari pencatatan Medical Record di RSUP Dr. M. Djamil Padang di tahun 2009, angka kejadian perdarahan postpartum tercatat sebanyak 73 (4,81\%) ibu dari 1515 orang ibu bersalin. Tahun 2010 terdapat
$47(3,63 \%)$ ibu yang mengalami perdarahan postpartum dari 1295 orang ibu bersalin. Walaupun antara 2009 2010 terjadi penurunan jumlah kejadian perdarahan postpartum, namun pada tahun 2011 terjadi peningkatan yaitu terdapat $110 \quad(7,5 \%)$ ibu yang mengalami perdarahan postpartum dari 1.463 ibu bersalin. Tahun 2012 terdapat 72 (4,29\%) ibu yang mengalami perdarahan postpartum dari 1.677 ibu bersalin. $^{3}$

Menurut penelitian Stanton et al, upaya penanganan perdarahan postpartum adalah dengan pemberian oksitosin, dimana oksitosin mempunyai peranan penting dalam merangsang kontraksi otot polos uterus sehingga perdarahan dapat teratasi. Hasil dari penelitiannya menunjukkan rata-rata jumlah perdarahan setelah plasenta lahir yang diberikan injeksi oksitosin lebih sedikit dibandingkan tanpa diberikan injeksi oksitosin. ${ }^{4}$

Menurut penelitian Thornton et al, menjelaskan bahwa oksitosin dapat dihasilkan oleh tubuh pada saat proses persalinan. Kadar oksitosin akan meningkat pada kala III oleh karena pengurangan metabolisme secara tiba-tiba karena pelepasan plasenta, dimana plasenta merupakan sumber utama oksitosin. Akibat pelepasan plasenta, hipotalamus terstimulasi untuk menghasilkan hormon oksitosin. ${ }^{5}$

Hormon oksitosin dapat dihasilkan melalui rangsangan pemijatan oksitosin. Hal ini juga dibahas dalam penelitian Rapaport et al tentang pengaruh pemijatan pada hipotalamus-hipofisis-adrenal dan fungsi imun dalam kesehatan, dengan hasil penelitian menyatakan adanya peningkatan hormon oksitosin dan menekan arginine-vasopressin (AVP) serta menekan hormon cortisolsetelah dilakukan pemijatan. ${ }^{6}$

Penelitian Morhenn et al menjelaskan adanya hubungan pemijatan otot tulang belakang dengan peningkatan kadar oksitosin dan menurunkan kadar adrenocorticotropin hormon (ACTH), nitric oxide (NO) dan beta-endorphin (BE). Perbandingan efek pemijatan 
pada kelompok intervensi dan kelompok kontrol mempunyai perbedaan yang signifikan. ${ }^{7}$

Pengaruh pemijatan juga dibahas oleh Young et al yang menyatakan bahwa pemijatan akan meningkat akan kadar hormon oksitosin. Pijat oksitosin adalah suatu tindakan pemijatan otot tulang belakang mulai dari cervical 7 sampai scapula yang akan mempercepat kerja saraf parasimpatis untuk menyampaikan perintah ke otak bagian belakang sehingga oksitosin keluar. ${ }^{8}$

Menurut penelitian Khairani tentang pengaruh pijat oksitosin terhadap involusi uterus pada ibu post partum di ruang post partum kelas III RSHS Bandung, dengan hasil penelitian adanya pengaruh pemijatan oksitosin terhadap involusi uterus pada ibu post partum di Ruang Post Partum Kelas III RSHS Bandung. ${ }^{9}$

Penelitian Hamranani di Rumah Sakit Wilayah Kabupaten Klaten menyatakan bahwa ada hubungan pemijatan oksitosin dengan involusi uterus $(p<0,05) \cdot{ }^{10}$

Tujuan penelitian yaitu untuk mengetahui pengaruh perbedaan kadar oksitosin melalui pemijatan oksitosin terhadap jumlah perdarahan pada ibu 2 jam postpartum.

\section{METODE}

Penelitian ini menggunakan desain eksperimen dengan bentuk post test only design. Pengukuran ini dilakukan setelah kelompok intervensi diberikan pijat oksitosin dan pada kelompok kontrol yang tidak diberikan pijat oksitosin. Tempat penelitian di Bidan Praktek Mandiri Padang dan Pariaman dan Laboratorium Biomedik Univeristas Andalas Padang. Penelitian ini dilaksanakan selama \pm 6 bulan.

Populasi dalam penelitian ini adalah ibu post partum yang melahirkan secara normal di Bidan Praktek Mandiri Padang dan Pariaman. Subjek penelitian ini adalah semua ibu postpartum yang melahirkan secara normal yang memenuhi kriteria inklusi dan ekslusi. Kriteria inklusi dalam penelitian ini adalah ibu 2 jam post partum hari pertama yang mengalami persalinan normal, tidak menderita penyakit sistemik, laserasi jalan lahir sudah diatasi dengan baik, responden sudah melakukan gerakan miring kanan miring kiri 2 jam post partum, kehamilan tunggal, bayi melakukan IMD, ibu postpartum yang bayinya hidup, ibu tidak mengalami retensio plasenta, ibu dengan gravida 2, tidak mengalami polihidramnion, tidak dilakukan induksi persalinan. Jumlah sampel yang diteliti adalah 32 responden untuk kelompok kontrol dan 32 responden untuk kelompok intervensi.

Pengukuran dilakukan dengan cara kelompok intervensi yang dipijat oksitosin menggunakan protokol pemijatan oksitosin dan untuk menilai jumlah perdarahan kala IV peneliti melakukan penimbangan underpad kemudian dianalisa dengan rumus volume $(\mathrm{ml})=$ berat/massa jenis darah $(1,056)$. Pengumpulan data kadar oksitosin untuk pengambilan darah peneliti dibantu oleh petugas laboratorium. Pemeriksaan kadar oksitosin dengan Human Oxytocin Elisa Kit kemudian diolah di Laboratorium Biomedik Fakultas Kedokteran Unand.

Analisa data yang dilakukan untuk mengetahui perbedaan dua variabel antara variabel independent dengan variabel dependent dilakukan dengan uji independen $t$ test. Untuk mengetahui faktor yang mempengaruhi jumlah perdarahan 2 jam postpartum dapat dilihat dari analisis regresi,yang mana untuk mengetahui bentuk hubungan antara dua variabel, sedangkan untuk mengetahui eratnya hubungan dapat diketahui dengan analisis korelasi.

\section{HASIL}

Hasil penelitian ini dilakukan secara random blok dengan jumlah subyek penelitian 64 orang yang memenuhi kriteria inklusi dan setuju untuk ikut dalam penelitian. Sebanyak 32 orang diberi perlakuan pemijatan oksitosin selama 15 menit sebagai kelompok intervensi, dan 32 orang tidak diberikan perlakuan pemijatan oksitosin yang disebut kelompok kontrol. Sepuluh menit jam kedua pada kelompok intervensi dilakukan pengambilan darah sebanyak satu kali dan 25 menit jam kedua dilakukan pengambilan darah untuk kelompok kontrol. Data yang diperoleh dikelompokkan dan ditabulasi sesuai dengan karakteristik masingmasing variabel dan didapatkan hasil penelitian. 
Tabel 1. Karakteristik responden

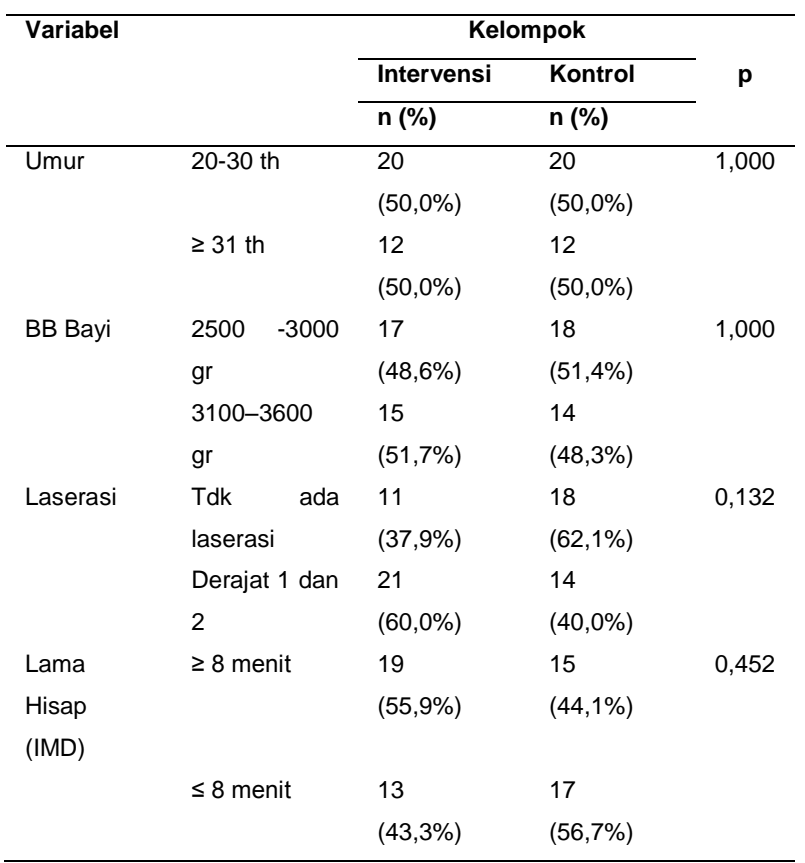

Hasil uji statistik perbedaan rerata pada karakteristik variabel umur ibu, berat badan bayi,derajat laserasi dan lama menghisap pada saat IMD didapatkan $p>0,05$. Hal ini menunjukkan bahwa secara karakteristik variabel umur ibu, berat badan bayi, derajat laserasi dan lama menghisap pada saat IMD menunjukkan tidak ada perbedaan yang bermakna antara kelompok intervensi dengan kelompok kontrol, sehingga tidak mempengaruhi jumlah perdarahan dan kadar oksitosin.

Usia di bawah 20 tahun dan di atas 35 tahun merupakan usia beresiko untuk hamil dan melahirkan. Usia kehamilan yang paling aman untuk melahirkan adalah usia 20 - 30 tahun. ${ }^{11,12}$

Berat badan bayi yang lebih dari 4000 gram (makrosomia) menyebabkan pendarahan postpartum, karena dapat menyebabkan uterus terlalu meregang, dengan overdistensi tersebut dapat menyebabkan uterus atonik. ${ }^{13}$

Perdarahan yang cukup banyak dapat terjadi dari robekan yang dialami selama proses melahirkan baik yang normal ataupun dengan tindakan.Laserasi jalan lahir memberi kontribusi terhadap terjadinya perdarahan postpartum sebesar $4-5 \%$.

Tabel 2. Rerata kadar oksitosin pada ibu 2 jam post partum

\begin{tabular}{lll}
\hline Variabel & Mean \pm SD & Minimal-Maksimal \\
\hline Kadar & $38.51 \pm 19.47$ & $14.885-79.902$ \\
Oksitosin & $\mathrm{pg} / \mathrm{ml}$ & $\mathrm{pg} / \mathrm{ml}$ \\
\hline
\end{tabular}

Kadar oksitosin minimal pada ibu 2 jam postpartum sebesar $14.885 \mathrm{pg} / \mathrm{ml}$ dan kadar oksitosin maksimal sebesar $79.902 \mathrm{pg} / \mathrm{ml}$, dengan rerata kadar oksitosin ibu 2 jam postpartum adalah $38.51 \mathrm{pg} / \mathrm{ml}$.

Menurut penelitian Rapaport et al, rata-rata kadar oksitosin pada kelompok yang dilakukan masase Swedish sebesar $27.6 \pm$ SD $35.5 \mathrm{pg} / \mathrm{ml}$,sedangkan pada kelompok yang dilakukan pemijatan lembut mempunyai rata-rata kadar oksitosin sebesar $80.1 \pm \mathrm{SD} 42.0 \mathrm{pg} / \mathrm{ml}{ }^{6}$

Menurut penelitian Morhenn et al, rata-rata kadar oksitosin pada kelompok sebelum dilakukan pemijatan pada otot tulang belakang bagian atas sebesar 190.37士 SD $122.04 \mathrm{pg} / \mathrm{ml}$ dan kadar oksitosin setelah dilakukan

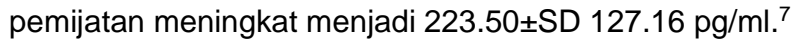

Menurut penelitian Thornton et al menjelaskan bahwa 10 wanita yang diberikan oksitosin pada saat kelahiran plasenta menunjukkan peningkatan konsentrasi plasma oksitosin.Kadar oksitosin pada saat pengeluaran janin (Kala II) adalah sebesar 3,9 pmol/l kemudian meningkat pada saat kelahiran plasenta (Kala III) menjadi $23 \mathrm{pmol} / \mathrm{l}$ setelah pemberian oksitosin. Peneliti juga menjelaskan bahwa dari 15 wanita yang tidak diberikan oksitosin, 9 orang memiliki waktu kelahiran plasenta yang normal dan 4 orang lagi tidak, namun plasenta dapat lahir walau dengan waktu yang lebih lama dan 2 orang yang mengalami perdarahan postpartum akibat manual plasenta.Plasma oksitosin meningkat pada saat Kala II dengan kadar oksitosin sebesar 4,2 pmol/l, kemudian meningkat saat kelahiran plasenta menjadi $17 \mathrm{pmol} / \mathrm{l} .^{5}$

Fungsi oksitosin pada persalinan kala tiga adalah menyebabkan kontraksi rahim. Asal usul fluktuasi endogen oksitosin tidak dapat ditentukan dari studi ini, tetapi beberapa pengamatan menunjukkan bahwa kenaikan tersebut disebabkan oleh peningkatan pelepasan oksitosin dari ibu dan janin. Oksitosin janin dapat berkontribusi dan beredar pada ibu sehingga konsentrasi plasma oksitosin meningkat selama kala I dan II persalinan, namun pada kala III oksitosin akan dihasilkan oleh tubuh ibu sendiri karena terjadi pengurangan metabolisme secara tiba-tiba akibat pelepasan plasenta, sehingga hipotalamus terstimulasi merangsang hormon oksiosin kemudian dialirkan melaluihipofisis posterior, kemudian menstimulasi jalan lahir selama persalinan. ${ }^{5}$ 
Oksitosin menginduksi otot polos miometrium uteri pada persalinan.Pemicu sintesis reseptor oksitosin dapat berupa peningkatan rasio estrogen terhadap progesteron seiring berkurangnya konsentrasi hormon progesteron selama persalinan.Oksitosin dilepaskan dari hipofisis posterior selama persalinan akibat rangsangan dilatasi serviks yang mengirimkan serat aferen ke sistem saraf pusat sehingga menyebabkan kelenjer hipofisis posterior meningkatkan sekresi oksitosinnya. ${ }^{14}$

Tabel 3. Rata-rata jumlah perdarahan pada ibu 2 jampostpartum

\begin{tabular}{lll}
\hline Variabel & Mean \pm SD & $\begin{array}{l}\text { Minimal - } \\
\text { Maksimal }\end{array}$ \\
\hline Jumlah & $211.03 \mathrm{ml} \pm 71.082$ & $110 \mathrm{ml}-385$ \\
Perdarahan & $\mathrm{ml}$ & $\mathrm{ml}$ \\
\hline
\end{tabular}

Jumlah perdarahan minimal pada ibu 2 jam postpartum sebanyak $110 \mathrm{ml}$ dan jumlah perdarahan maksimal sebanyak $385 \mathrm{ml}$ dengan rata-rata jumlah perdarahan ibu 2 jam postpartum adalah $211.03 \mathrm{ml}$.

Hasil dari data penelitian Stanton et al rata-rata jumlah perdarahan setelah plasenta lahir diberikan injeksi oksitosin adalah sebesar $185.5 \mathrm{ml}$ dan rata-rata jumlah perdarahan setelah plasenta lahir tanpa diberikan injeksi oksitosin $229.5 \mathrm{ml}^{4}$

Hormon oksitosin akan memicu kontraksi otot polos pada uterus sehingga akan terjadi involusi uterus dan mencegah terjadinya perdarahan. Oksitosin merupakan suatu hormon yang dapat memperbanyak masuknya ion kalsium kedalam intrasel. Keluarnya hormon oksitosin akan memperkuat ikatan aktin dan myosin sehingga kontraksi uterus semakin kuat dan proses involusi uterus semakin bagus. Hormon oksitosin yang dilepas dari kelenjar hipofisis memperkuat dan mengatur kontraksi uterus, mengompresi pembuluh darah dan membantu proses hemostasis. Kontraksi dan retraksi otot uterus akan mengurangi suplai darah ke uterus. Proses ini akan membantu mengurangi bekas luka implantasi plasenta serta mengurangi perdarahan. ${ }^{15}$

Hasil analisis pengaruh pemijatan oksitosin terhadap kadar oksitosin pada ibu 2 jam post partum mempunyai rata-rata kadar oksitosin lebih tinggi pada kelompok intervensi dibandingkan dengan kelompok kontrol.
Tabel 4. Pengaruh pemijatan oksitosin terhadap kadar oksitosin pada ibu 2 jam postpartum

\begin{tabular}{lll}
\hline $\begin{array}{l}\text { Pemijatan } \\
\text { Oksitosin }\end{array}$ & $\begin{array}{l}\text { Kadar Oksitosin } \\
\text { Mean } \pm \text { SD }\end{array}$ & p \\
\hline Intervensi & $47.16 \pm 17.583 \mathrm{pg} / \mathrm{ml}$ & 0,001 \\
Kontrol & $29.86 \pm 17.532 \mathrm{pg} / \mathrm{ml}$ & \\
\hline
\end{tabular}

Perbedaan kadar oksitosin antara kelompok intervensi dengan kelompok kontrol yaitu sebesar 17.3 $\mathrm{pg} / \mathrm{ml}$. Hasil uji statistik diperoleh nilai $\mathrm{p}<0,05$ yang artinya ada perbedaan bermakna kadar oksitosin pada ibu 2 jam postpartum antara kelompok intervensi dengan kelompok kontrol.

Hasil analisis pengaruh pemijatan oksitosin terhadap kadar oksitosin pada ibu 2 jam postpartum mempunyai rata-rata kadar oksitosin lebih tinggi pada kelompok intervensi dibandingkan dengan kelompok kontrol. Perbedaan kadar oksitosin antara kelompok intervensi dengan kelompok kontrol yaitu sebesar 17.3 $\mathrm{pg} / \mathrm{ml}$. Hasil uji statistik diperoleh nilai $\mathrm{p}<0,05$ yang artinya ada perbedaan bermakna kadar oksitosin pada ibu 2 jam postpartum antara kelompok intervensi dengan kelompok kontrol.

Menurut penelitian Thornton et at menjelaskan bahwa 10 wanita yang diberikan oksitosin pada saat kelahiran plasenta menunjukkan peningkatan konsentrasi plasma oksitosin. Kadar oksitosin pada saat pengeluaran janin (Kala II) adalah sebesar 3,9 pmol/l kemudian meningkat pada saat kelahiran plasenta menjadi $23 \mathrm{pmol} / / \mathrm{l}$ setelah pemberian oksitosin. Peneliti juga menjelaskan bahwa dari 15 wanita yang tidak diberikan oksitosin, 9 orang memiliki waktu kelahiran plasenta yang normal dan 4 orang lagi tidak, namun plasenta dapat lahir walau dengan waktu yang lebih lama dan 2 orang yang mengalami perdarahan postpartum akibat manual plasenta. Plasma oksitosin meningkat setelah kelahiran bahu depan dengan kadar oksitosin sebesar 4,2 pmol/l, kemudian meningkat saat kelahiran plasenta menjadi $17 \mathrm{pmol} / .^{5}$

Penelitian Young et al menjelaskan adanya hubungan pemijatan yang dilakukan di daerah veretebralis L4 sampai S1 terhadap sistem saraf otonom sehingga HRV, serum kortisol dan tingkat norepinefrin akan diturunkan dan meningkatkan kadar oksitosin. ${ }^{8}$

Penelitian Morhenn et al menjelaskan adanya 
hubungan pemijatan otot tulang belakang dengan peningkatan kadar oksitosin dan menurunkan kadar adrenocorticotropin hormon (ACTH), Nitric Oxide (NO) dan Beta-Endorphin (BE). Perbandingan efek pemijatan pada kelompok intervensi dan kelompok kontrol mempunyai perbedaan yang signifikan $p<0,05{ }^{7}$

Dengan adanya pemijatan oksitosin, terjadi rangsangan di korda spinalis yang mana berfungsi sebagai penghubung saraf antara otak dan sistem saraf perifer. Semua komunikasi ke atas dan ke bawah korda spinalis terletak di jaras-jaras (traktus) asendens yang menyalurkan sinyal dari masukan aferen ke otak. Substansia grisea yang terletak di tengah korda spinalis mengandung penghubung antarneuron yang terletak antara masukan aferen dan keluaran eferen serta badan sel neuron eferen. Serat aferen dan eferen yang masing-masing membawa sinyal ke dan dari korda spinalis, menyatu menjadi saraf spinalis. Saraf-saraf ini melekat ke korda spinalis berpasangan di sepanjang korda. Neuron inhibitorik dan neuron kolimergik eksitatorik membuat kontak sinaps dengan neuron oksitosin neuro sekretorik di nucleus paraventrikularis dan supraoptikus. Kemudian hipotalamus memproduksi hormon oksitosin dan dialirkan menuju hipofisis posterior, oksitosin menuju ke uterus maka mioendometrium akan mengalami kontraksi sehingga merangsang terjadinya kontraksi dan mengurangi jumlah perdarahan pada kala IV. ${ }^{14}$

Melalui pijatan atau rangsangan pada otot tulang belakang, neurotransmitter akan merangsang medulla oblongata langsung mengirim pesan ke hipotalamus menuju hipofisis posterior mengeluarkan hormon oksitosin yang menyebabkan otot polos uterus berkontraksi dengan baik. Dengan pijatan di otot tulang belakang ini akan merileksasi ketegangan dan menghilangkan stress, oleh sebab itu akan melancarkan proses pengeluaran hormon oksitosin menuju ke uterus.

Tabel 5. Pengaruh pemijatan oksitosin terhadap jumlah perdarahan pada ibu 2 jam postpartum

\begin{tabular}{lcl}
\hline $\begin{array}{l}\text { Pemijatan } \\
\text { Oksitosin }\end{array}$ & $\begin{array}{c}\text { Jumlah Perdarahan } \\
\text { Mean } \pm \text { SD }\end{array}$ & \\
\hline Intervensi & $175.00 \pm 48.894 \mathrm{ml}$ & 0,001 \\
Kontrol & $247.06 \pm 72.093 \mathrm{ml}$ & \\
\hline
\end{tabular}

Hasil analisis pengaruh pemijatan oksitosin terhadap jumlah perdarahan pada ibu 2 jam postpartum mempunyai rata-rata jumlah perdarahan lebih sedikit pada kelompok intervensi dibandingkan dengan kelompok kontrol. Perbedaan jumlah perdarahan pada kelompok intervensi dengan kelompok kontrol sebesar $72.06 \mathrm{ml}$. Hasil uji statistik diperoleh nilai $p<0,05$ yang artinya ada perbedaan bermakna jumlah perdarahan pada ibu 2 jam postpartum antara kelompok intervensi dengan kelompok kontrol.

Menurut penelitian Khairani tentang Pengaruh Pijat Oksitosin terhadap Involusi Uterus pada lbu Postpartum di ruang post partum kelas III RSHS Bandung, dengan hasil adanya pengaruh pemijatan oksitosin terhadap involusi uterus pada ibu post partum di Ruang Post Partum Kelas III RSHS Bandung. Dapat digambarkan bahwa proses involusi uterus yang dinilai dari penurunan tinggi fundus uterus pada responden intervensi yang dipijat oksitosin mengalami involusi uterus normal lebih banyak daripada involusi uterus yang tidak dipijat oksitosin. Berdasarkan hasil uji statistik didapatkan ada pengaruh pijat oksitosin terhadap proses involusi uterus yang ditunjukkan dengan nilai $\mathrm{p}<0.05$ yang berarti Ho ditolak. ${ }^{9}$

Penelitian Hamrarani di Rumah Sakit Wilayah Kabupaten Klaten menyatakan bahwa ada hubungan pemijatan oksitosin dengan involusi uterus $(p<0,05) .{ }^{10}$

Hormon oksitosin akan memicu kontraksi otot polos pada uterus sehingga akan terjadi involusi uterus dan mencegah terjadinya perdarahan. Oksitosin merupakan suatu hormon yang dapat memperbanyak masuknya ion kalsium kedalam intrasel. Keluarnya hormon oksitosin akan memperkuat ikatan aktin dan myosin sehingga kontraksi uterus semakin kuat dan proses involusi uterus semakin bagus. Hormon oksitosin yang dilepas dari kelenjar hipofisis memperkuat dan mengatur kontraksi uterus, mengompresi pembuluh darah dan membantu proses hemostasis. Kontraksi dan retraksi otot uterin akan mengurangi suplai darah ke uterus. Proses ini akan membantu mengurangi bekas luka implantasi plasenta serta mengurangi perdarahan. ${ }^{15}$

Melalui pijatan atau rangsangan pada otot tulang belakang, neurotransmitter akan merangsang medulla oblongata langsung mengirim pesan ke hipotalamus menuju hipofisis posterior, dan mengeluarkan hormon oksitosin yang menyebabkan otot polos uterus berkontraksi dengan baik sehingga dapat mengurangi jumlah perdarahan pada ibu postpartum. 


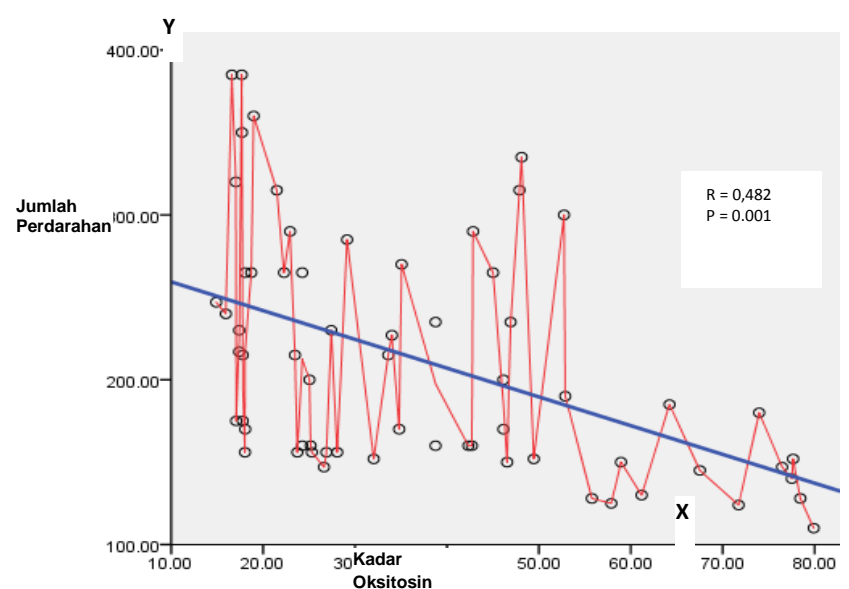

Gambar 1. Korelasi kadar oksitosin terhadap jumlah perdarahan pada ibu 2 jam postpartum

Hasil uji korelasi didapatkan hubungan kadar oksitosin terhadap jumlah perdarahan ibu 2 jam postpartum menunjukkan hubungan sedang ( $r=0,482)$. Hubungan dua variabel menunjukkan liner negatif artinya semakin tinggi kadar oksitosin maka semakin sedikit jumlah perdarahan pada ibu 2 jam postpartum. Hasil uji statistik didapatkan ada pengaruh kadar oksitosin terhadap jumlah perdarahan pada ibu 2 jam postpartum $(p<0,05)$.

Hasil dari data penelitian Stanton et al, rata-rata jumlah perdarahan setelah plasenta lahir diberikan injeksi oksitosin adalah sebesar $185.5 \mathrm{ml}$ dan rata-rata jumlah perdarahan setelah plasenta lahir tanpa diberikan injeksi oksitosin $229.5 \mathrm{ml}^{4}$

Menurut penelitian Thornton et al, menjelaskan bahwa 10 wanita yang diberikan oksitosin pada saat kelahiran plasenta menunjukkan peningkatan konsentrasi plasma oksitosin. Kadar oksitosin pada saat pengeluaran janin (Kala II) adalah sebesar 3,9 pmol/I kemudian meningkat pada saat kelahiran plasenta menjadi $23 \mathrm{pmol} / \mathrm{l}$ setelah pemberian oksitosin. Peneliti juga menjelaskan bahwa dari 15 wanita yang tidak diberikan oksitosin,9 orang memiliki waktu kelahiran plasenta yang normal dan 4 orang lagi tidak, namun plasenta dapat lahir walau dengan waktu yang lebih lama dan 2 orang yang mengalami perdarahan postpartum akibat manual plasenta. Plasma oksitosin meningkat setelah kelahiran bahu depan dengan kadar oksitosin sebesar 4,2 pmol/l, kemudian meningkat saat kelahiran plasenta menjadi $17 \mathrm{pmol} / \mathrm{I}^{5}$
Oksitosin menginduksi otot polos miometrium uteri pada persalinan. Pemicu sintesis reseptor oksitosin dapat berupa peningkatan rasio estrogen terhadap progesteron seiring berkurangnya konsetrasi hormon progesteron selama persalinan. Oksitosin dilepaskan dari hipofisis posterior selama persalinan akibat rangsangan dilatasi serviks yang mengirimkan serat aferen ke sistem saraf pusat sehingga menyebabkan kelenjer hipofisis posterior meningkatkan sekresi oksitosinnya. ${ }^{14}$

Hormon oksitosin akan memicu kontraksi otot polos pada uterus sehingga akan terjadi involusi uterus dan mencegah terjadinya perdarahan. Oksitosin merupakan suatu hormon yang dapat memperbanyak masuknya ion kalsium kedalam intrasel.Keluarnya hormon oksitosin akan memperkuat ikatan aktin dan myosin sehingga kontraksi uterus semakin kuat dan proses involusi uterus semakin bagus. Hormon oksitosin yang dilepas dari kelenjar hipofisis memperkuat dan mengatur kontraksi uterus,mengompresi pembuluh darah dan membantu proses hemostasis. Kontraksi dan retraksi otot uterus akan mengurangi suplai darah ke uterus.Proses ini akan membantu mengurangi bekas luka implantasi plasenta serta mengurangi perdarahan. ${ }^{15}$

Menurut asumsi peneliti, kadar oksitosin akan meningkat jika ibu dalam keadaan rileks dan jauh dari kondisi stress, sehingga produksi oksitosin dapat meningkat dan dapat mengurangi jumlah perdarahan postpartum.Pada penelitian ini sebagian ibu bersalin mengalami laserasi,hal ini menyebabkan rasa nyeri dan rasa cemas terhadap luka laserasi. Nyeri luka laserasi dapat menjadi salah satu penghambat pengeluaran hormon oksitosin. Ibu yang mempunyai tingkat nyeri yang tinggi dapat memblokade reflek pengeluaran hormon oksitosin.

\section{KESIMPULAN}

Terdapat peningkatan kadar oksitosin pada ibu 2 jam postpartum yang dilakukan pemijatan oksitosin. Terdapat penurunan jumlah perdarahan ibu 2 jam postpartum yang dilakukan pemijatan oksitosin. Semakin tinggi kadar oksitosin maka jumlah perdarahan semakin sedikit. 


\section{UCAPAN TERIMA KASIH}

Terima kasih kepada BPM Yetti Latief, S.SiT, BPM Rika Hardi, S.SiT, BPM Afniwati, M.Kes, dan BPM Farida Leli S.SiT sebagai tempat penelitian.

\section{DAFTAR PUSTAKA}

1. Survey Demografi Kesehatan Indonesia. BPSBKKBN-KemenKes RI-Measure DHS.ICF International:2012.

2. Saifuddin AB. Perdarahan setelah bayi lahir. Buku Acuan Nasional Pelayanan Kesehatan Maternal dan Neonatal. Jakarta.YBSP.2009:173-81.

3. MR.RSUP Dr.M.Djamil. Padang; 2012.

4. Stanton CK., Samuel N, Luke Cmu. Effect on postpartum hemorrhage of prophylactic oxytocin (10 iu) by injection by community health officers in Ghana. A Community-Based,Cluster-Randomized Trial.Australia. The Journal University of Adelaide. 2013;10:524.

5. Thornton S, Davison JM, Baylis PH. Plasma oxytocin during third stage of labour. Comparison of Natural and Active Management.Newcastle. Department of Obstetrics and Gynaecology Journal. 2004;297.

6. Rapaport MH, Pamela S, Catherine BA. Preliminary study of the effects of repeated massage on hypothalamic-pituitary-adrenal and immune function in healthy individuals. a study of mechanisms of action and dosage. The Journal Of Alternative And Complementary Medicine.Los Angeles,Department of Psychiatry and Biobehavioral Sciences, David Geffen School of Medicine at University of California. 2012;18:789-97.

7. Morhenn V, Laura E, Beavin MA. massage increase oxytocin and reduces adrenocorticotropin hormone in humans. San Diego. University of California
SanDiego Medical Center. J. Alternative Therapies. 2012;18:6.

8. Young HL, Bit RP, Sung HK. The effects of heat and massage application on autonomic nervous system. Korea. Department of Rehabilitation Medicine, Wonju Christian Hospital,Yonsei University Wonju College of Medicine. Yonsei Med J.2011;52:982-9.

9. Khairani L. Efektifitas antara pijat oksitosin dan breast care terhadap produksi ASI Ibu postpartum dengan sectio secarea di RSUD Banyumas. Purwokerto. Universitas Jendral Sudirman, Fakultas Kedokteran dan IImu Kesehatan. Student Ejournal, Journal_unpad.ac.id. 2013:579.

10. Hamrarani ST. Pengaruh pemijatan oksitosin terhadap involusi uterus pada ibu postpartum yang mengalami persalinan lama di rumah sakit wilayah Kabupaten Klaten (tesis). Jakarta. FIK Universitas Indonesia. 2010: 978.

11. Depkes RI. Asuhan essensial pencegahan dan penanggulangan segera komplikasi persalinan dan bayi baru lahir. Edisi Revisi. Jakarta. JNPK-KR.2008.

12. Killewo J, Borghi J, Sabina N. Comparison of Costs of Home and Facility-Based Basic Obstetric Care in Rural Bangladesh. London School of Hygiene \& Tropical Medicine Journal. 2008;7:225.

13. Prawirohardjo S. Perdarahan pascapersalinan. Imu Kebidanan. Jakarta: Yayasan Bina Pustaka Sarwono Prawirohardjo. 2010:334-530.

14. Greenstein B, Diana W. Hormon Oksitosin. Alih Bahasa: At a Glance Sistem Endokrin. Edisi ke-2. Jakarta. Erlangga.2010:71-3.

15. Bobak, Lowdermilk, Jensen. Perdarahan Pasca partum. Dalam: Buku Ajar Keperawatan Maternitas. Edisi ke-4. Alih Bahasa: Maria A Wijayanti. Peter I. Anugerah. Jakarta.:EGC; 2005. hlm.234-51. 